\title{
Research
}

\section{Temporal Stability in Fishing Spots: Conservation and Co- Management in Brazilian Artisanal Coastal Fisheries}

\author{
$\underline{\text { Alpina Begossi }}^{1}$
}

\begin{abstract}
The management of small-scale artisanal fisheries in Brazil should be a priority because of their importance as a source of food for internal markets and their location in sites with high biodiversity, such as the Atlantic Forest coast. Fishing spots, territories, and sea tenure have been widely studied within artisanal fisheries, and, in this study, a fishing spot of this type may be a defended area or an area that imposes rules for users, making the exclusion of outsiders feasible, or even a place in which fishing occurs with some exclusivity. This analysis takes into account the importance of fishing areas for the conservation of artisanal fishing in Brazil and the relative temporal stability of these areas. In particular, examples of the use of the marine space on the coast of Brazil in areas such as Rio de Janeiro, São Paulo, and Bahia States are presented. Fishing spots used by artisanal fishers were marked using a Global Positioning System (GPS). An informal division of the marine space and high temporal stability, often in the range of 10-30 $\mathrm{yr}$, in the use of the fishing spots were found. For some fishing areas, information published in the 1960s provided a relevant comparison for the current use of the fishing spots at sea. Such information is very helpful for the management of artisanal fishing in Brazil because tourism has increased in some areas, recreational fishers have been fishing in marine spots used by artisanal fishers, and industrial fishers are spread over a wide range of the marine space in these coastal waters. This stability in the use of marine space among artisanal fishers plus local rules support the case for local co-management of artisanal fisheries. Reserving areas for artisanal fishers and understanding the behavior of other users are essential aspects for the management and conservation of artisanal fishing in Brazil.
\end{abstract}

Key Words: artisanal fisheries; Amazon; Atlantic Forest coast, Brazil; co-management; territoriality; fishing accords

\section{INTRODUCTION}

The management of coastal waters should be a priority in Brazil, considering the number of smallscale fisheries along its coast and the importance of artisanal fishing as a source of food for the Brazilian population. Coastal artisanal fisheries in Brazil are an important source of employment and food for local communities, contributing 40-60\% of marine fish production (Silvano 2004). Many small communities, such as those along the Atlantic Forest coast, rely on fish as a source of protein, because fish represent 50-68\% of the animal protein in their diet (Begossi et al. 2000). Other authors have stressed the importance of local coastal artisanal fishers and of their conservation (Diegues 1983).
One of the crucial aspects of the mechanisms for conserving natural resources in fisheries, other than monitoring species and regulating the gear used, is controlling the space used by fishers, including their capacity to exclude outsiders. This is especially true when we observe that other coastal fisheries in the world have control of the space they use. For example, the Japanese coastal fisheries have controlled their shores since 1902, when village sea territories were mapped and registered in the Okinawa prefectural fisheries office (Akimichi and Ruddle 1984). In addition to controlling the marine space as a prerequisite for success, resource management should be able to set access limits on resources and restrict harvesting. In other words, it is important to define who is going to fish, how much 
fish will be taken out, and which species are targeted.

Territoriality has been one of the classic behaviors among fishers that has helped to exclude outsiders and maintain aquatic resource availability for the local artisanal fisheries. Territories have been owned or defended by families, groups, communities, and villages, among others, as shown by Forman (1967), Acheson (1972), Berkes (1985), McCay and Acheson (1987), and among Brazilian fishers, as shown by Cordell (1985, 1989), Begossi (1995, 1998a, 2001a,b, 2004a), and Seixas and Begossi (1998). Definitions of the Brazilian pesqueiro, a fishing spot with some type of tenure, as well as differences in territories and fishing areas are found in Cordell (1989) and in Begossi (2004a).

Many authors have shed light on analyses of the management of the commons (McCay and Acheson 1987), on different kinds of management regimes and property rights (Berkes 1989), and on research programs and theoretical insights concerning institutions and collective actions for the management of natural resources (Ostrom 1990). Reviews of the theory and analytical tools related to the management of common-pool resources are found in Feeny et al. (1990), Ruttan (1998), Burke (2001), and Dietz et al. (2002). As suggested by Agrawal (2002), difficulties in managing commonpool resources occur when there are many users, when boundaries are unclear, and when users are scattered over a large area.

In spite of the observation by Burger et al. (2001) that the spatial scale of the resource, the temporal scale, and especially the congruence between the scales of the system and of the jurisdictions are important factors when making decisions about management and governance, considerations of time are often absent in the literature. In a literature review by Agrawal (2002), in which the various conditions necessary for the sustainability of a common management are cited, the temporal stability of local rules or institutions is not taken into account. The instability of institutions, including their possible temporal shifts, is one of the factors of uncertainty. However, uncertainty in the literature is often related to environmental uncertainty (Kopelman et al. 2002), especially in marine fisheries (Wilson 2002), but not necessarily to institutional uncertainty. More recently, a study that looked at temporal and spatial scales in the context of social memory, adaptive learning, and local institutions was conducted among the Anishinaabe people of Ontario, Canada (DavidsonHunt and Berkes 2003).

The temporal scale as it relates to the existence of local rules and institutions in the use of resources is seldom taken into account in studies, because comparative temporal data are especially difficult to obtain. Most small-scale fisheries are located in developing countries, and data on fish landings and fishing spots used are often unavailable. There are, of course, exceptions. For example, in Jamaica, fishery surveys are carried out every $10 \mathrm{yr}$ (Berkes et al. 2000). Such information, or comparable information obtained from diachronic data, is key and much needed to verify the possibilities of a comanagement process. In a community whose fishing areas and rules change often, it is difficult to get fishers and environmental agents involved in co-management, because the rules and areas used are not clearly defined.

Berkes (1985) provides information on some of the mechanisms used by fishers to control resources at many different territorial levels and for many fisheries in the world, including individual or family parcels in Mexico, licensed individual use rights in Canada, and territories controlled by longhouses in Borneo. Other classical studies on territorial behaviors include a group of lobster fishers, i.e., the harbor gangs, on the coast of Maine, USA. Their territorial system was the result of competition between groups of lobster fishers (Acheson 1972, 1981, 1987). Acheson (1997) also obtained comparative historical data and records for in-depth analyses of the lobster fishery in Maine, including its economical cycles and recoveries.

In Brazil, data on coastal fisheries, especially on fish landings and fishing grounds, have been collected in research projects since 1985 (Begossi 1998a, $2001 a, b)$. In the present study, we obtained data from Bahia, São Paulo, and Rio de Janeiro; these can be compared to other data collected at different sites over 10-30 yr (Fig. 1). The major objective of this study was to analyze stability in the use of fishing spots as an incipient or local rule for the coastal artisanal fisheries and as an important mechanism that could support the conservation of fishing areas in these small-scale communities. 
Fig. 1. Research sites in Bahia, Rio de Janeiro, and São Paulo States, Brazil.

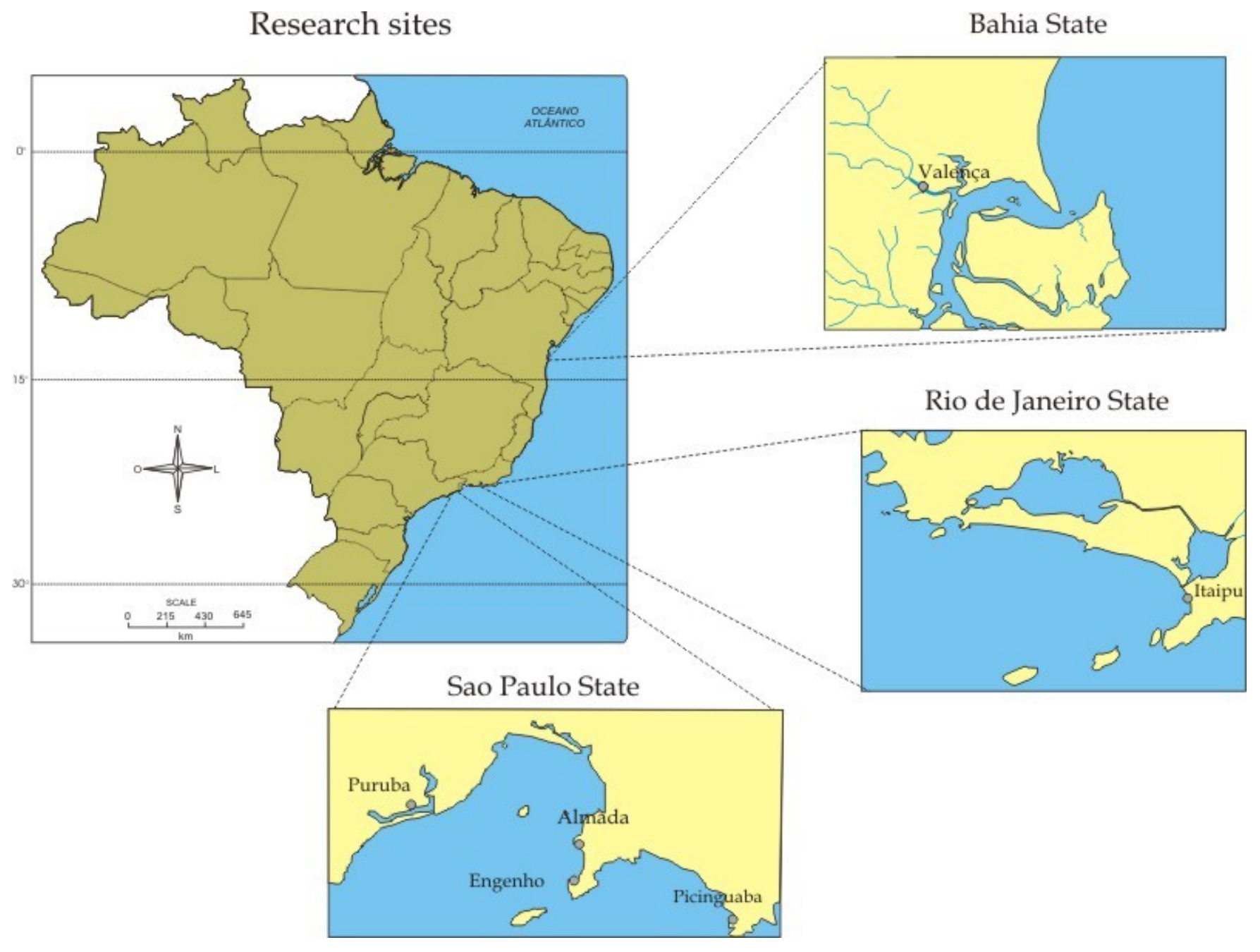

\section{Fishing communities, local rules, and sites}

In coastal Brazil, the control of marine space by local artisanal fishers is often difficult to observe because of the absence of direct or apparent conflicts among users from coastal communities. However, a division of the marine space is apparent, perhaps as a result of the restrictions imposed by simple technologies, e.g., motorized and paddled canoes, or as an outcome of previous conflicts, or even as a precautionary behavior that guarantees the extraction of fish by each of the small-scale fishing communities along the coast. Thus, even indirectly, fishers have shown the existence of informal or customary mechanisms for sharing the use of marine space (Begossi 2001a,b, 2004a). For example, artisanal fisher technology, mostly represented by paddled or motorized canoes or aluminum boats, restricts fisher mobility. As a consequence, fishing usually occurs in spots located close to the fishers' residences. At the same time, some distant fishing spots are occasionally shared by fishers from different fishing communities and, in this case, no conflicts are observed, because such spots are used only sporadically. This behavior is shown by fishers from the coast of Rio de Janeiro who belong to the jurisdiction of the fishing associations of Copacabana (Nehrer and Begossi 
2000) and the Itaipu beaches of Colonia de Pescadores Z-13 and Z-7; the Rasa and Redonda Islands are sporadically frequented by fishers from both communities (Fig. 2).

However, the occurrence of incipient accords, customary laws, or local rules may not be enough to guarantee the conservation of fishing areas. The conservation of artisanal fisheries depends, among others things, on the capacity to exclude outsiders and to create institutions that assimilate local rules for the use of marine space. Acheson and Knight (2000) suggest that social conventions emerge because of the need to coordinate activities. Such a capacity might be associated with (1) the degree of cohesion and robustness of local organizations, including their ability to defend the marine space, e.g., through territories, and (2) interactions or communications with government agencies in support of local initiatives and the ability to form a basis for co-management. According to Jentoft (2003), such a concept is broad, but it represents a collaborative and participatory process of regulatory decision making among representatives of user groups, government agencies, research institutions, and other stakeholders. Examples of interactions between government institutions and local fishers in Latin America are given in Begossi and Brown (2003).

The division of space for fishing is a necessary condition for avoiding conflicts over resources, because it minimizes overlap in the search for resources. However, the division of space alone is not enough to conserve resources, unless such use is stable over time. For this reason, even though Brazilian artisanal coastal fishers have some informal division in the use of the local fishing spots (Begossi 2001a,b) and the most frequently used spots are those located close to residences, there was a need to determine whether the locations of the fishing spots changed over time. Therefore, three coastal Brazilian areas were studied. The first, the fishing village of Valença, was also studied by Cordell $(1974,1978,1985,1989)$ in the 1960s; it is located on the northeastern coast of Brazil, in Bahia State. The second community, Itaipu Beach, which we studied from 2001 to 2003, is located in the city of Niterói, Rio de Janeiro State (Figs. 1 and 2). This area was also studied in the 1970 s by Lima and Pereira (1997). The third area includes communities from the Ubatuba district on the coast of the State of São Paulo, i.e., Puruba and Picinguaba Beaches. These were studied in 1992-1993 (Begossi 1995,
$1998 a$ ). In the present study, I show that the spots used for fishing today are the same as those used in the past; thus, they are stable over time.

\section{METHODS}

After interviews with fishers and after choosing an experienced fisher as an informant, the fishing spots were marked in the three areas studied. Data on fishing and on the community were available from the results of earlier studies in Valença, Bahia (Cordell 1974, 1978, 1989); in Itaipu, Rio de Janeiro (Lima and Pereira 1997, Barbosa et al. 2004, Begossi 2004a); and in Puruba and Picinguaba, São Paulo (Begossi 1995, 1998a,b, 2004a,b, Lopes 2004).

Fieldwork was carried out in the three coastal areas between 2001 and 2003. To mark the locations of the fishing spots, i.e., the pesqueiros, a GPS Garmin III + and Garmin V were used at Itaipu and Valença, and Puruba Beach, respectively. At Valença, Bahia, and Itaipu Beach, Rio de Janeiro, procedures included interviews using open-ended questionnaires; the data collected included each fisher's name, occupation, age, type of fishing gear used, prey captured, and the locations of fishing spots used, among other information. Data from Valença were collected during one visit in February 2002, fish were collected for identification, and fishers from the neighborhood of Tento were interviewed. The choice to interview fishers from Tento came after preliminary interviews at Valença, which identified Tento as the place in which most local fishers live and land their fish. Interviews were performed using the snowball method (Bailey 1978) in which, at the end of each interview, fishers were asked to give the name(s) of other fishers who had experience and knowledge in the field. Using this method, I interviewed 18 fishers in the neighborhood of Tento.

The fishing association, Colônia de Pescadores $\mathrm{Z}-15$, is located in Tento and has a small port in the estuary in which one of the landing points was located. A sketch from Cordell (1989) was used to verify the use of the 258 fishing spots that were cited in the studies he carried out in the 1960s. After interviewing 18 local fishers, three experienced fishers were selected to follow us by boat to mark the spots used to fish. To analyze the adequacy of the sample of fishers taken, a graphic analysis of the sampling effort was plotted (Fig. 3). Figure 3 shows that the sampling effort should have been greater, 
Fig. 2. Fishing spots used by fishers from Copacabana Beach, marked in 1998 at Colônia de Pescadores Z-13, Rio de Janeiro State, and Itaipu Beach, marked in 2002-2003 at Colônia de Pescadores Z-7, Niterói, Rio de Janeiro State.

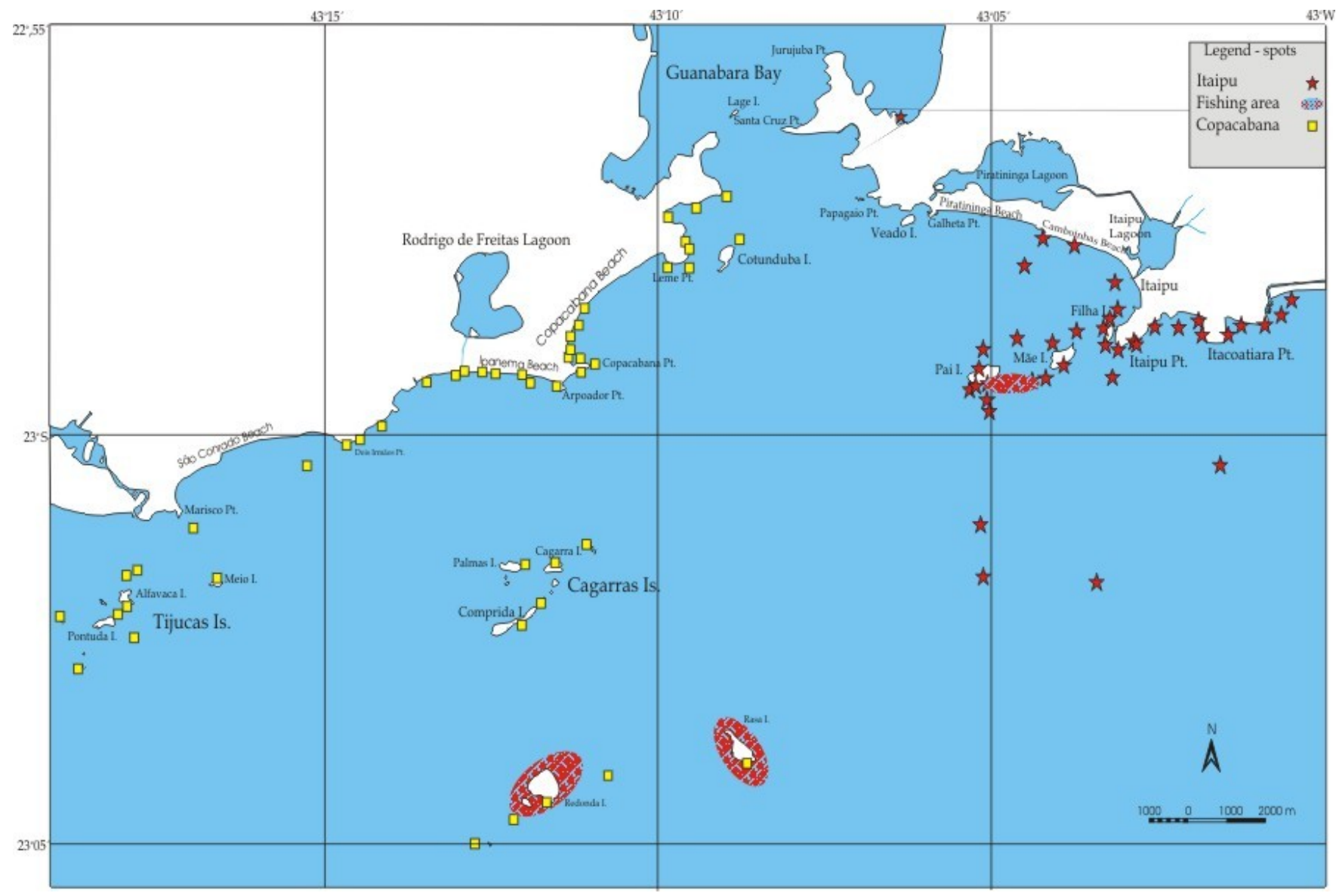

because the sigmoid curve is still increasing and the addition of other interviews would have increased the number of spots cited. However, this problem was solved when the 258 fishing spots listed by Cordell (1989) were presented to the fishers during interviews, after they had listed the main spots currently used.

At Colônia de Pescadores Z-7 in Itaipu Beach, Niterói, the research project included the sampling of fish caught at landing points, fish collection to identify species, and the characterization of the fishery. Monthly visits to Itaipu Beach were made between December 2001 and April 2003, with the exception of August 2002. In addition to the collection of data at the main landing point on Itaipu
Beach, data were collected directly, using a boat, from the areas in which fishing activities occurred, a method I refer to as the "fishing approach." This approach consists of marking the coordinates of each spot using a GPS and acquiring data, e.g., time, fish caught, location name, on fishing activity when fishers are at sea. Using this method, together with interviews done at landing points on Itaipu Beach, data on the spots most frequently used and on 68 fishing trips during the months of January, February, March, September, and October 2002 were obtained. In this community, fish landings, technology, species caught, and the use of marine areas by fishers were studied. Following the analysis of the sampling effort for Valença, the relationship between the numbers of spots sampled and the 
Fig. 3. The cumulative number of new fishing spots given in interviews vs. sampling effort in Valença, Bahia State, and Itaipu, Niterói, Rio de Janeiro State.

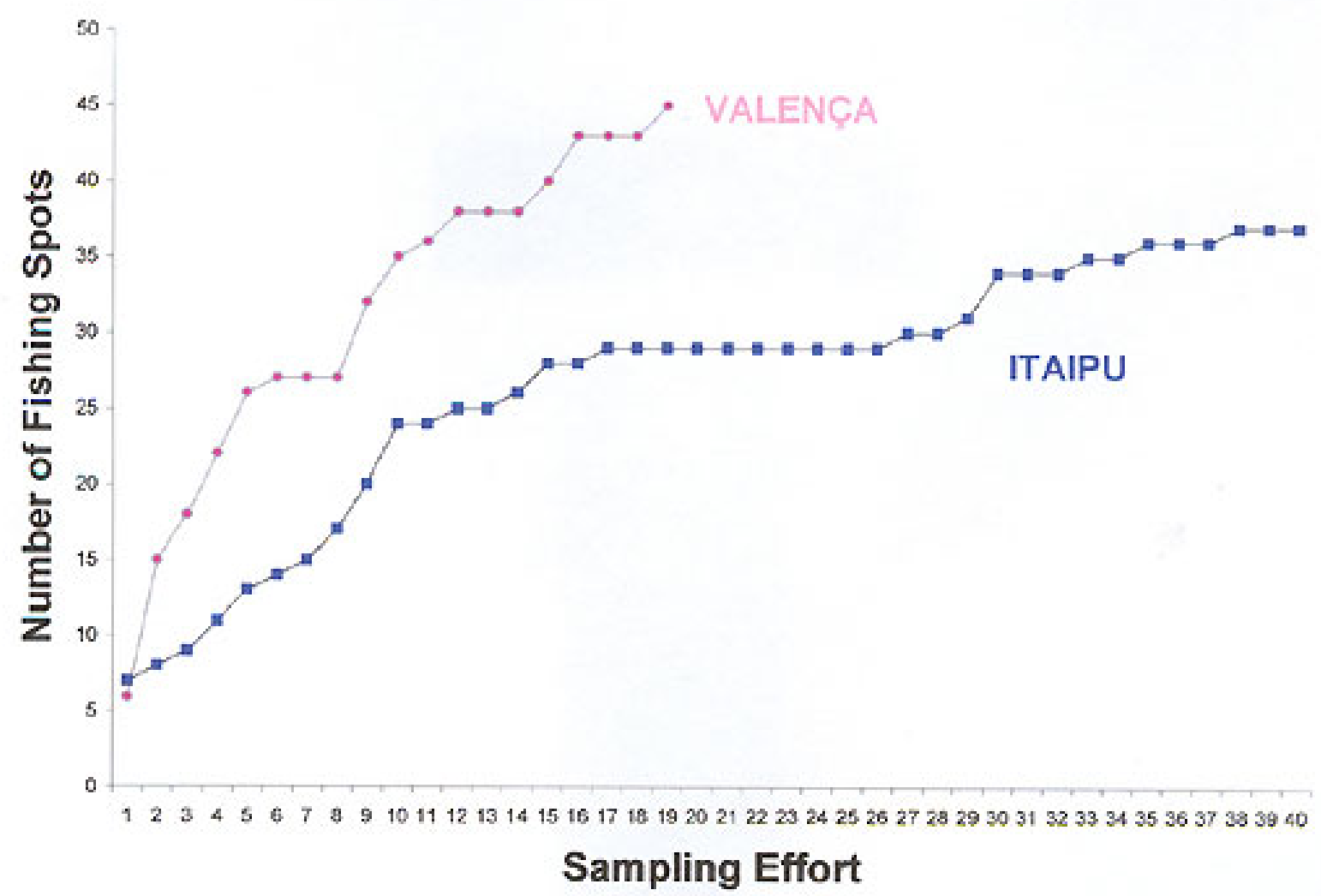

numbers of interviewees was plotted (Fig. 3). In the case of Itaipu, the sampling effort was sufficient, as can be seen in Fig. 3. No matter how many interviewees I added, the number of spots tended to remain constant.

Data at Puruba and Picinguaba Beaches were collected during earlier research projects in 19921993 and during other visits to these small villages, with particular attention to data on the use of the fishing space in April and December 2003. During the visit to Puruba, an experienced fisher known from the previous research carried out there agreed to follow us in a boat to mark the current fishing spots used for local fishing. Earlier information on the Puruba Beach small-scale fishing community and on the use of its fishing space is published in Begossi (1995,1998b). In Picinguaba, spots were marked using information provided by just one fisher. After it was noticed that only a few spots had been marked, the information was checked with another fisher who marked very few additional spots. For these two communities, data on fishing spot names were available and collected during earlier projects; these were used to produce maps of the fishing spots currently used (Begossi 1995, 1998a). After the study at Puruba and Picinguaba, a neighboring beach, Almada community, was included to acquire information on the use of fishing spots with the help of an informant (Fig. 1).

\section{RESULTS}

The mechanisms of spot division by artisanal fishers to determine the use of the marine space by fishers from Itaipu Beach, Niterói, and Copacabana, Rio de Janeiro, are illustrated in Fig. 2. Earlier studies on 
artisanal fishers from Copacabana Beach were conducted by Nehrer (1997) and by Nehrer and Begossi (2000). Founded in 1923, the Colônia de Pescadores Z-13 is one of the oldest fishermen's associations in Rio de Janeiro State (Nehrer and Begossi 2000).

In Fig. 2, it can be observed that the two artisanal fishing communities are located at opposite ends of Guanabara Bay, and most of the spots used are close to the fishing associations, Copacabana and Itaipu, or the fishers' residences. Exceptions include distant spots, such as Rasa and Redonda Islands (Fig. 2), which are used sporadically by fishers from both communities. These results reinforce the findings of earlier studies carried out in other Atlantic coastal communities (Begossi 2001a,b), which demonstrate that there is an informal division of spots among fishers and that this may be useful for conservation, because it represents a nonoverlapping process in the extraction of fish resources.

Local rules on the use of the marine space, i.e., forms of sea tenure, were observed in earlier studies or during the data collection phase of the current study. In Valença, Bahia, Cordell (1989) observed no formal status in the forms of sea tenure; instead, he noted that the use of the marine space was regulated by an honor code that the fishers called respeito, meaning social respect. At Itaipu Beach, Lima and Pereira (1997) observed "First Comer's Rules," a behavior that is still seen today. At Puruba, rights acquired by the frequency of use of some spots by the same fishers were observed (Begossi 1998a), and these rights seem to have been maintained within the same family $10 \mathrm{yr}$ later (Lopes 2004). At Picinguaba, no reference to local rules could be found during this study or in earlier research in that area (Begossi 1995).

\section{The temporal stability of fishing spots used by the coastal artisanal fishers}

\section{Valença, Bahia State}

Cordell (1989) recorded the fishing spots used by fishers in Valença during the 1970s. In these earlier studies, he analyzed the behavior of fishers toward the local ecological conditions such as high tide variations in the Valença estuary (Cordell 1978), carrying capacity (Cordell 1974), and territoriality, i.e., sea tenure (Cordell 1989).
Nowadays, Valença's artisanal fishers often use nets to catch shrimp and fish. The nets used most often for fishing during the period studied by Cordell (1989), the rede de calão, is a type of shallow-water purse seine that is still used for fish. However, shrimp fishing has increased over the past few years; locally, the net used for shrimp is called a redinha. Although the fishing techniques are similar, the redinha is smaller than the calão, measuring $50-60 \mathrm{~m}$ in length, whereas the calão is more than $200 \mathrm{~m}$ long (Begossi 2004a). Nevertheless, the same spots are used in net fishing for both shrimp and fish, except that the redinha is used over a smaller area.

Data collected during interviews (Table 1) and by the two local informants who went with us by boat, pointing out each spot used in "Valença 2," are shown on the map in Fig. 4. I observed that the spots were the same as those sketched by Cordell (1989), and that, aside from some changes in the fishery such as the inclusion of shrimp fishing using the redinha, the known and used spots had not changed over time. These results show that these fishing spots have been used for more than $30 \mathrm{yr}$.

To be sure about the locations and the use of spots, I marked the locations a second time with the assistance of an informant who fishes in Valença with a hook and line, rather than using the calão technique (Fig. 4). In Fig. 4, the areas marked with this informant included only some of the fishing spots used for net fishing with the calão, according to Cordell (1989), and with the common shrimp net or redinha, as observed in the present study. We note in Table 1 that the fisher who used the spots just for line fishing had knowledge of only $14 \%$ of the spots. This is understandable, because Cordell's study focused on fishing with the calão and did not examine hook and line fishing. Thus, the spots that he recorded were used essentially for the calão and are currently used for shrimp net fishing with the redinha as well. However, these spots are not used for line fishing (Fig. 4.).

About $20 \mathrm{~km}$ from Valença, there is a small fishing community called Guaibim where lobster is one of the targets. I interviewed a local fisher and asked him about the 258 spots indicated in Cordell's study (1989), but he had knowledge of only $12 \%$ of them, all of which were located near Guaibim (Fig. 4). Such results reinforce the conclusions that: 
Table 1. Results of interviews in the neighborhood of Tento in Valença, Bahia State, Brazil. Fishers 4, 5, and 14 were informants who helped to mark the fishing spots by boat. The fishers who were not born in Valença lived there between the ages of 15 and 56.

\begin{tabular}{ccccc}
\hline \hline 2 & 59 & 100 & Shrimp net & Camamú, Bahia \\
3 & 38 & 95 & beach seine & Valença \\
4 & 68 & 95 & Fish net & Nilo Peçanha, Bahia \\
5 & 65 & 91 & Shrimp net & N. da Rainha, Bahia \\
6 & 62 & 91 & Shrimp net & Valença \\
7 & 51 & 91 & Shrimp net & Valença \\
8 & 70 & 90 & Shrimp net & Valença \\
9 & 64 & 84 & Shrimp net & Valença \\
$10^{\dagger}$ & 72 & 75 & Shrimp and fish net, beach seine & Valença \\
$11^{\dagger}$ & 65 & 74 & Shrimp and fish net & Valença \\
12 & 38 & 68 & Fish net & Valença \\
13 & 42 & 64 & Shrimp net & Ituberá, Bahia \\
14 & 42 & 51 & Hook and line fishing & Valença \\
15 & 32 & 51 & Shrimp net & Valença \\
16 & 68 & 47 & Fish net & Valença \\
17 & 39 & 39 & Fish net & Camamú, Bahia \\
18 & 44 & 14 & Hook and line fishing &
\end{tabular}

$\dagger$ Ex-fisher, retired from fishing.

- fishers who use the calão or redinha nets at Valença fish mostly at spots that were registered by Cordell and also marked with a GPS and mapped in this study. These spots are located mostly within the Valença estuary;

- $\quad$ the high temporal stability of spots at Valença corresponds to the use of these spots for more than $30 \mathrm{yr}$, i.e., since the 1960s, when Cordell collected the data; and

- fishers in Valença and Guaibim in Bahia, as in other communities, tend to fish near their residences. This behavior represents a nonoverlapping use of the aquatic space to obtain resources, especially shrimp, fish, and lobster.

Another interesting observation in the study at Valença, Bahia, is that age is an important factor affecting the knowledge of fishing spots. As seen in Table 1, this type of a relationship is well illustrated by the linear regression between the number of spots known by fishers $(y)$ and their ages $(x)$, where $y=$ $33.15+2.78 x, R^{2}=0.49, \mathrm{df}=17, p<0.01$ (Begossi $2004 a)$.

\section{Itaipu Beach, Niterói, Rio de Janeiro State}

In the other community studied, Itaipu Beach, Niterói, Rio de Janeiro State, fishers often use a hook 
Fig. 4. Fishing spots marked by two informants in Valença, Bahia State, sites Valença 1 and 2, and Guaibim, Bahia State in 2002.

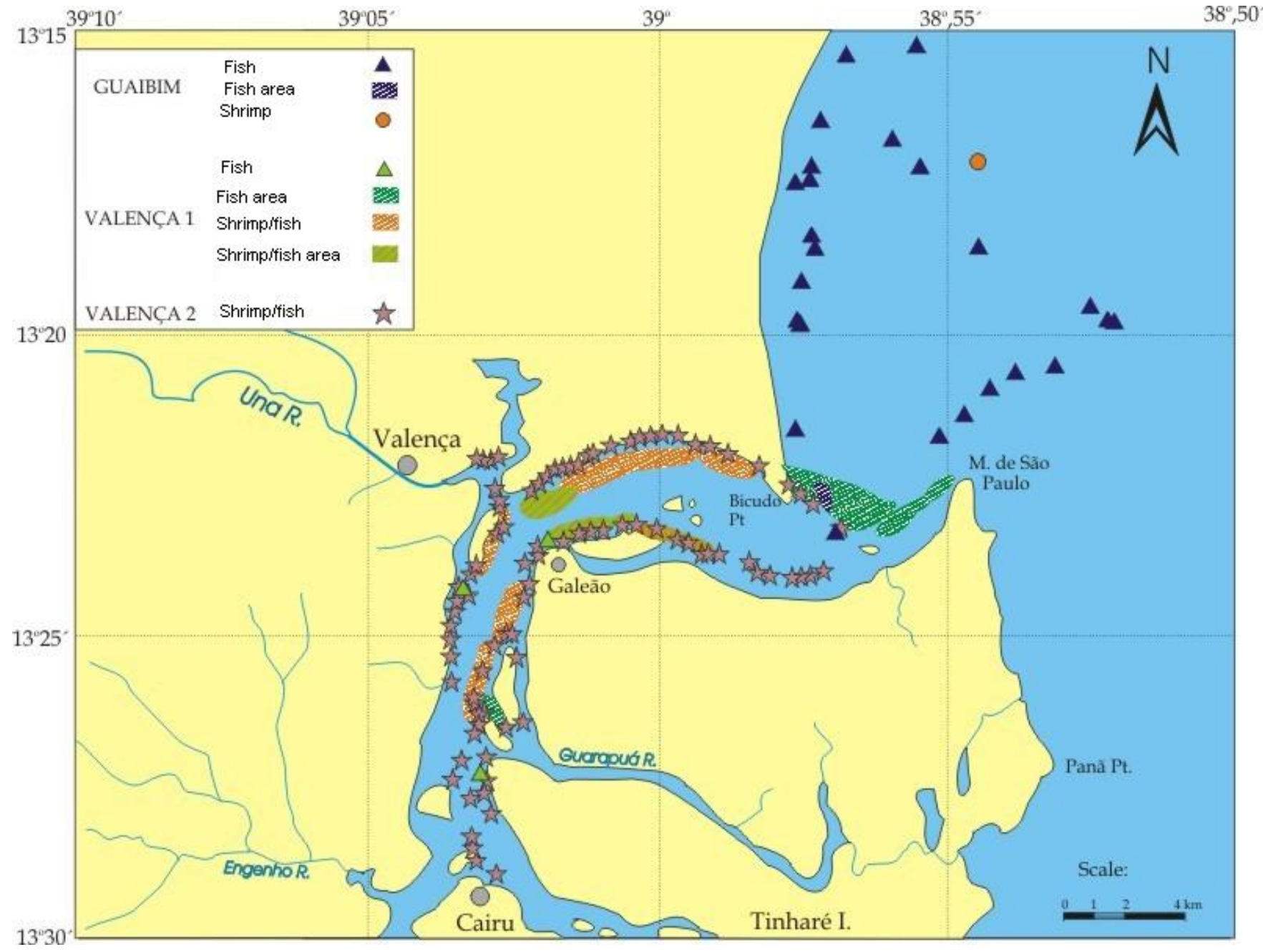

and line to catch fish, squid, (Loligo spp.), and cutlass fish or espada (Trichiurus lepturus), and they use gillnets and beach seines to catch other species such as Sciaenidae. Fishing occurs mostly at sea for fish and squid, but some shrimp fishing also takes place in the Itaipu Lagoon. Of the 142 fishing trips sampled, 100 used a hook and line, including hooks for fish and squid.

At Itaipu Beach, Rio de Janeiro, some spots have been used for more than $30 \mathrm{yr}$; a sketch drawn by Lima and Pereira (1997) based on data collected in approximately 1977 shows that the fishing areas are essentially the same when compared with those marked in 2002-2003 in this study (Fig. 2). The names of these fishing spots, along with the sketch by Lima and Pereira (1977) that includes the names of 64 fishing spots, were shown to the fishers during their interviews. Most interviewees recognized the majority of the fishing spots and considered them to be currently in use (Table 2).

Data collected at landing points from 142 fishing trips and from 68 approaches by boat to fishers during their fishing trips, when the current spot used to fish was marked, show that the three islands 
Table 2. Results of interviews performed at Itaipu, Niterói, Rio de Janeiro State, Brazil.

\begin{tabular}{|c|c|c|c|c|c|}
\hline Fisher & Age & $\begin{array}{l}\text { Fishing spots } \\
\text { known }(\%)\end{array}$ & $\begin{array}{l}\text { Years of local } \\
\text { residence }\end{array}$ & Place of birth & $\begin{array}{l}\text { Fishing gear } \\
\text { or } \\
\text { technique used }\end{array}$ \\
\hline 1 & 40 & 100 & 25 & Rio do Ouro & $\ldots$ \\
\hline 2 & 38 & 100 & 12 & Itaipu & Fish set gillnet \\
\hline 3 & 64 & 98 & 52 & Itaipu & $\begin{array}{l}\text { Line for squid } \\
\text { and fish }\end{array}$ \\
\hline 4 & 48 & 92 & 38 & Itaipu & Fish set gillnet \\
\hline 5 & 43 & 92 & 25 & $\begin{array}{l}\text { Engenho do } \\
\text { mato }\end{array}$ & $\begin{array}{l}\text { Line for squid } \\
\text { and fish }\end{array}$ \\
\hline 6 & 30 & 90 & 22 & Pendotiba & $\ldots$ \\
\hline 7 & 64 & 89 & 57 & Cafubá & $\ldots$ \\
\hline 8 & 47 & 85 & 20 & Niterói & $\begin{array}{l}\text { Line for squid } \\
\text { and fish }\end{array}$ \\
\hline 9 & $\ldots$ & 85 & $15-20$ & Alcântara & $\begin{array}{l}\text { Line for squid } \\
\text { and fish }\end{array}$ \\
\hline 10 & 48 & 84 & 30 & Niterói & $\begin{array}{l}\text { Line for squid } \\
\text { and fish }\end{array}$ \\
\hline 11 & 45 & 84 & 30 & Niterói & Beach seine \\
\hline 12 & 27 & 82 & 15 & Itaipu & $\ldots$ \\
\hline 13 & 37 & 79 & 25 & Rio do Ouro & Fish set gillnet \\
\hline 14 & 30 & 79 & 10 & Itaipu & $\begin{array}{l}\text { Line for squid } \\
\text { and fish }\end{array}$ \\
\hline 15 & 45 & 77 & 30 & Niterói & $\begin{array}{l}\text { Line for squid } \\
\text { and fish }\end{array}$ \\
\hline 16 & 42 & 77 & 15 & Rio do Ouro & $\begin{array}{l}\text { Line for squid } \\
\text { and fish }\end{array}$ \\
\hline 17 & 42 & 69 & 19 & Itaipu & $\begin{array}{l}\text { Line and } \\
\text { diving }\end{array}$ \\
\hline 18 & 53 & 62 & 27 & Itaipu & Fish set gillnet \\
\hline
\end{tabular}

closest to Itaipu Beach are the sites most often exploited. These are the Ilha Filha, also called the Ilha Menina and the Pimenta, the Ilha da Mãe, and the Ilha do Pai, commonly called the Primeira, Segunda, and Terceira, or First, Second, and Third Islands, respectively (Fig. 2). These islands included 81 of the 210 fishing trips in samples taken at landing points in 2002 that used the fishing approach method.

In further interviews carried out at landing points with the participation of 48 fishers, some 59 spots were cited as commonly used. In 17 of these citations, the three islands were grouped together; 
individually, First Island was cited seven times, Second Island seven times, and Third Island 11 times. The spots located at Itacoatiara Beach, the next beach to the north, were recognized by fishers (Table 1) and used in 22 of 210 fishing trips. Among the 59 spots mentioned in interviews, the spots cited by at least 10 fishers were the four mentioned above, along with Itaipuaçú and Rasa Islands (Fig. 2). This distant island, in spite of being mentioned in interviews as a visited site, was visited only four times. Redonda Island (Fig. 2) was mentioned by three fishers during the interviews. These results show that distant spots are used less frequently than those that are closer, such as the three islands mentioned above, and that the fishing spots used by fishers from Itaipu, listed by Lima and Pereira (1997) 30 yr ago, are still being used by the community of fishers from Itaipu Beach, Niterói.

\section{Puruba and Picinguaba, Ubatuba, São Paulo State}

Puruba Beach has a fishery that is dedicated especially to line fishing. It is located between two small rivers that run from the Atlantic Forest to the sea: the Puruba and the Quiririm. Fishing in 19921993 was for both subsistence and sale (Begossi 1995), but, according to recent data (Lopes 2004), fishing now occurs only for subsistence; catches include snook, mullets, and catfish, among others. In 1998, a sketch of eight fishing spots was made based on data obtained from 193 fishing trips (Begossi 1998a). The marking of fishing spots in 2003 , with the help of a fisher informant who was fishing in 1992-1993 and still fishes, confirms that the main spots used are mostly the same (Fig. 5). Lopes (2004) compared fish production and the use of spots for the two sets of data, observing that there had been no change in the use of the space for fishing but that there had been a decrease in the community's dependence on local fish for commercial purposes, along with a decrease in fish consumption and in local fish resources. However, the continuous use of the fishing spots for more than $10 \mathrm{yr}$ is similar to what was observed for Búzios Island, located on the northern coast of São Paulo, and for Sepetiba Bay, on the coast of Rio de Janeiro State (Begossi 2001a).

Picinguaba, a small beach located inside the Serra do Mar State Park, is inhabited by more than 100 families. Its population includes tourists and middle-class retirees, or persons who have migrated in an attempt to get away from life in huge southeastern Brazilian cities such as São Paulo; some of them are seeking a different life-style. In 1991-1992, four different types of fishing were found there: (1) the cerco, known to the Japanese as kaku-ami, a floating net that is disposed in a circle, marked with bamboo, and visited twice a day; (2) set gillnet fishing in paddled canoes; (3) hook and line fishing in the small local rivers of Rio da Fazenda and Rio Picinguaba; and (4) fishing embarcado, which means contractual fishing in trawlers from the cities of Santos and Rio de Janeiro, i.e., industrial fishing.

When I returned to Picinguaba in 2003, the small beach had been transformed into a narrow strip of sand. Canoe shelters were built there after the fishers sold their previous shelters, now vacation houses, to tourists (Fig. 6). Local fishing with the cerco and with set gillnets is still performed by a few fishers, but the absence of local fishers using paddled or motorized canoes for local fishing was noticeable. This community has suffered strong pressure from local environmental agencies to suspend fishing activities because it is located inside a State Park, with additional pressure from the external tourist economy that accompanies middle-class homeowners. Such pressures are also emphasized in other studies in Picinguaba (Masumoto 2003). In this study, data were obtained from two informants in Picinguaba. One of the informants gathered data from just two spots and Rapada Island. The fishing spots are located close to the islands facing Picinguaba Beach (Fig. 7).

In light of such results, I decided to mark the spots on the neighboring beach to the south, i.e., AlmadaEngenho Beach, locally called Almada, which was studied earlier by Hanazaki (1997), Hanazaki and Begossi (2000), and Hanazaki et al. (1996, 2000). This community, in spite of being so close to Picinguaba (Fig. 7), is located outside the park boundaries. It has an active fishing community, including a local organization that has been taking strict care of the beach with regard to cleanliness, an uncommon procedure on Brazilian beaches (Fig. 8 ). The spots used by this community were marked; Fig. 7 shows how fishers from Almada approach the area of Picinguaba. The informal division of spots was not in place in this case, probably because of the absence of local fishers in Picinguaba. Therefore, the criteria for stability in the use of these fishing spots appear to be associated with a right of use that is respected because of an effective fishing practice. The restrictions on fishing in the State Park seem to be a pressure that might disrupt an ongoing 
Fig. 5. Fishing spots marked at Puruba Beach, Ubatuba, São Paulo State, in 2003.

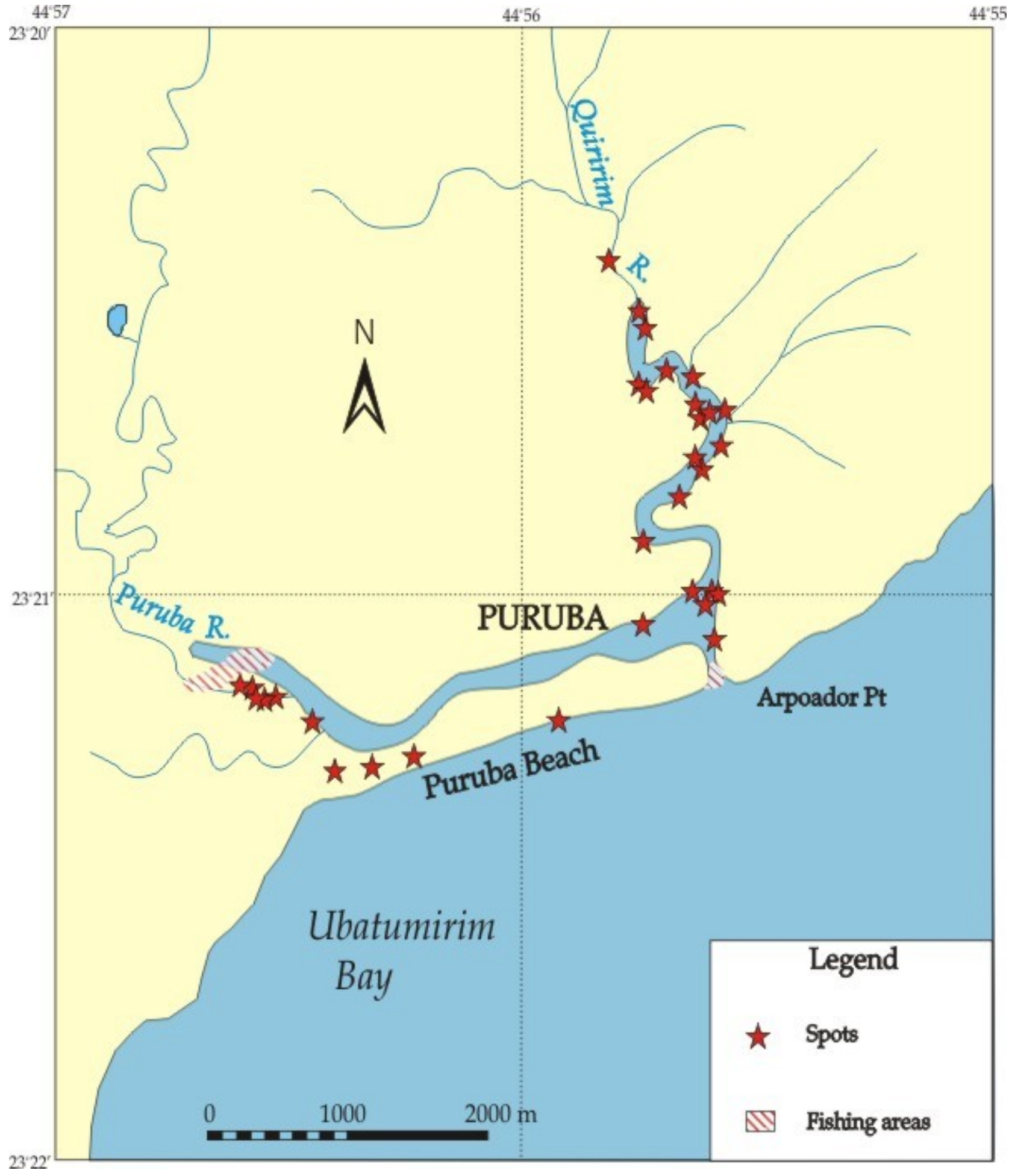


Fig. 6. Picinguaba Beach, located within the limits of the Serra do Mar State Park, São Paulo State.

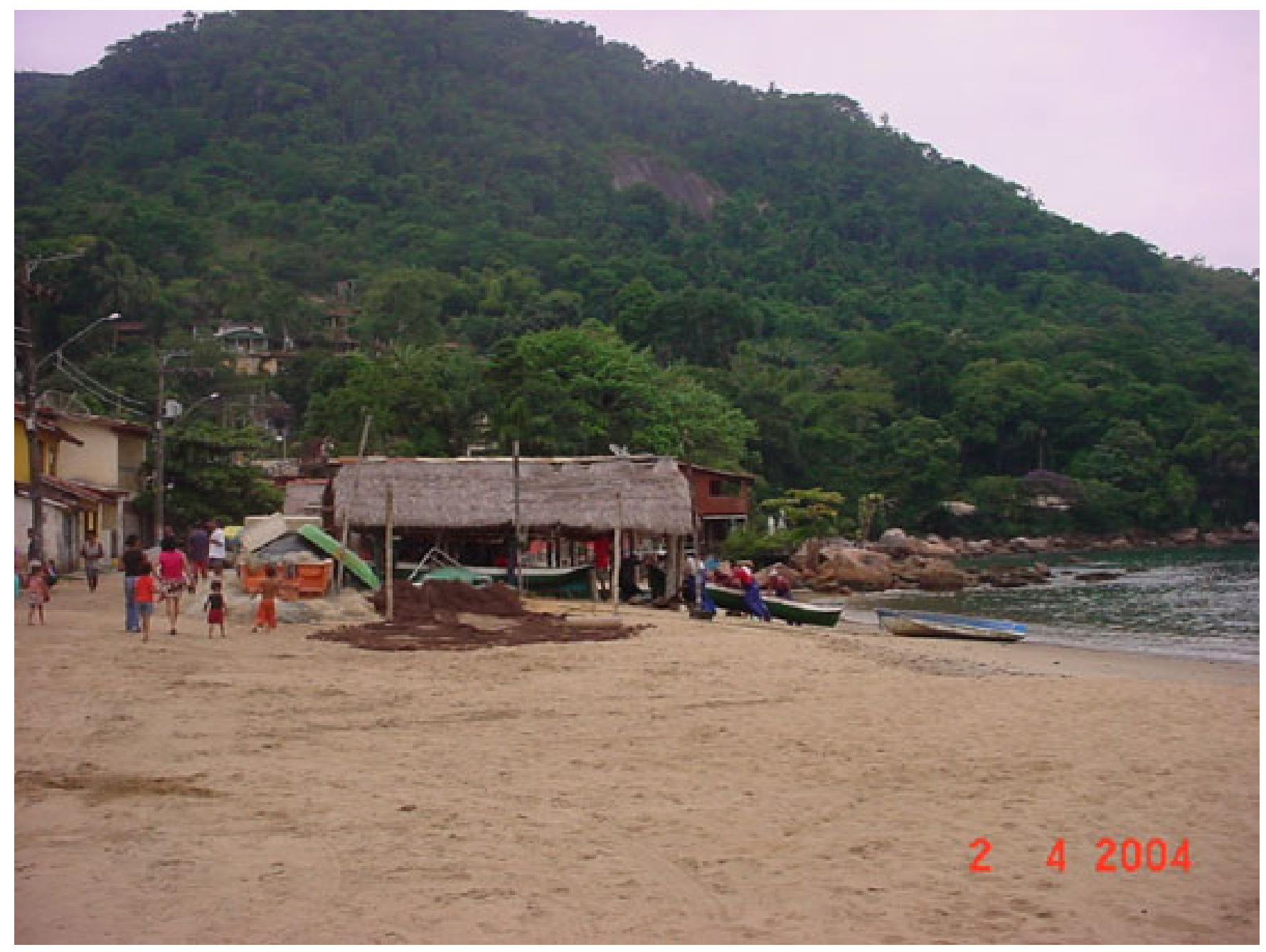

process of division of resources and of incipient local management. Seixas and Futemma (personal communication) are currently carrying out research dealing specifically with territories and institutional changes in Almada and its neighboring beaches.

\section{DISCUSSION}

The management of small-scale fisheries in developing countries such as Brazil faces obstacles because of the unavailability of data on fish landings, among other things, and because of the fact that many artisanal fisheries are located near protected areas and subject to restrictions on their subsistence or economic activities. For example, Puruba Beach is located in an area that is adjacent to the Serra do Mar State Park, Parque Estadual da Serra do Mar, and Picinguaba is located within the limits of this state park. Although the effort to promote co-management through extractive reserves, for instance, in inhabited Brazilian parks has been one of the strategies of the state or federal government agencies, this effort has, with a few exceptions, been based on top-down approaches (Begossi and Brown 2003, Begossi 2004a). There are, of course, particular cases in which fishers were given political space and a chance to experiment, as 
Fig. 7. Fishing spots marked at Picinguaba by two informants in 2003, and at Almada-Engenho Beaches, São Paulo State in 2004.

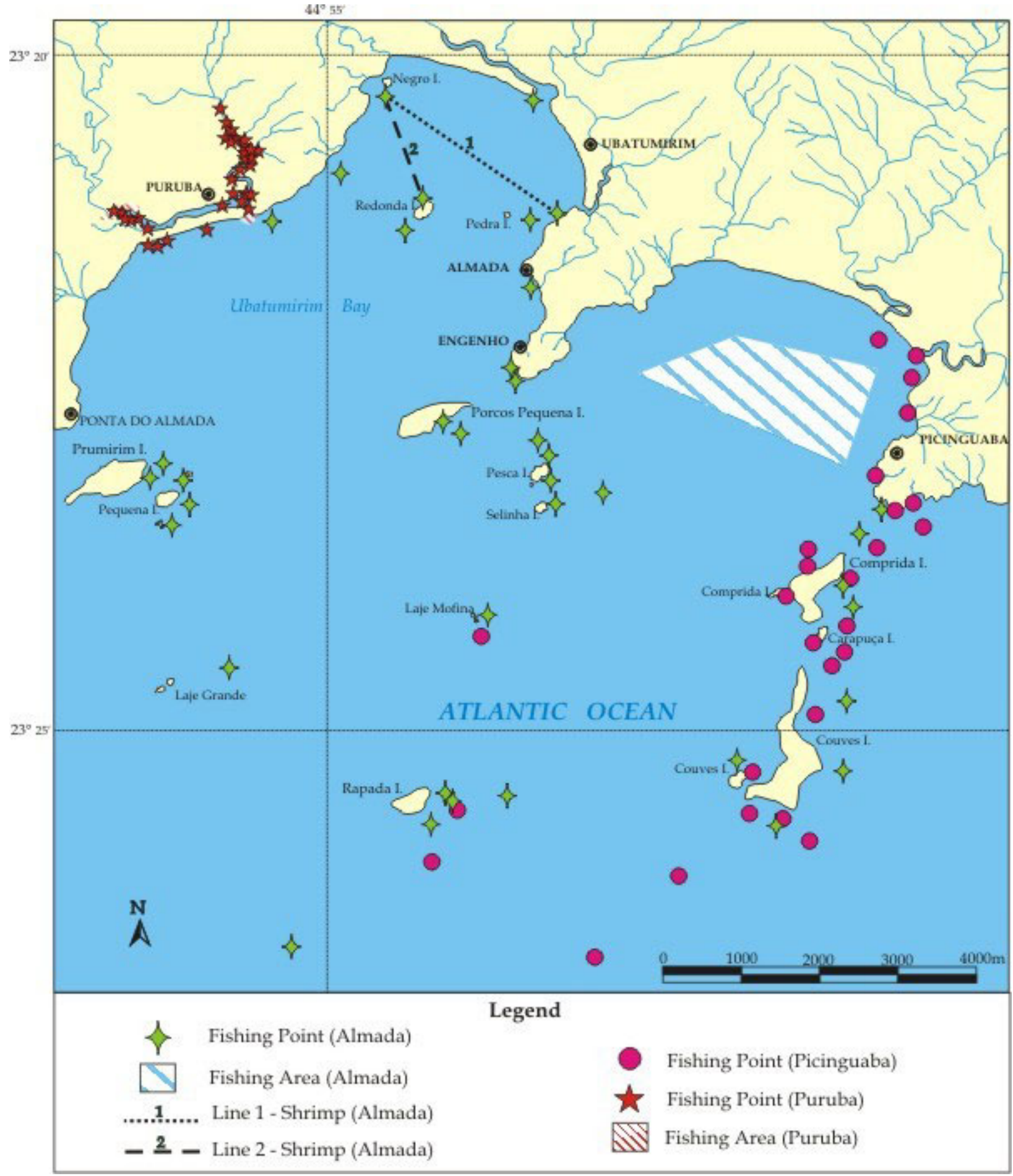


Fig. 8. Almada Beach, located outside of the boundaries of the Serra do Mar State Park, São Paulo State.

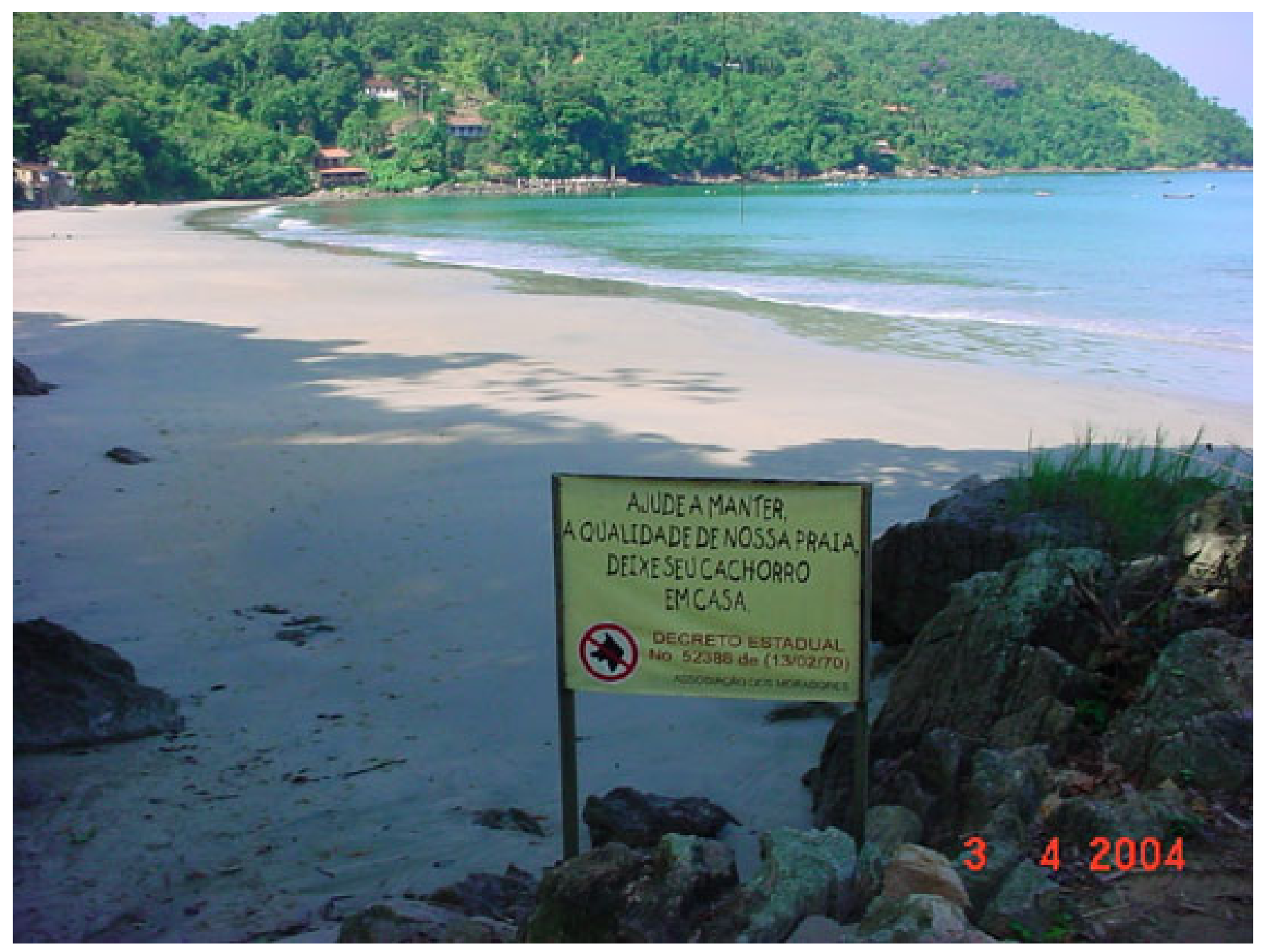

was the case with the fishers from Ibiraquera Lagoon in southern Brazil (Seixas and Berkes 2003). However, even in this case, the top-down approach to decision making practiced by state and federal government agencies has been emphasized (Seixas 2004a). In the southern Patos Lagoon in Brazil, Kalikoski et al. (2002) analyzed such topdown behavior, including the lack of incentives for and official intolerance of small-scale fishers.

In Brazil, the federal agency that addresses comanagement, the National Center for Traditional Populations and Sustainable Development (CNPT) of the Brazilian Institute for Environment and
Natural Renewable Resources (IBAMA), collectively referred to as CNPT-IBAMA, has attempted to organize extractive reserves along the southeastern Brazilian coast in spite of fishers' opinions. The IBAMA, using the "Extractive Reserve" slogan, has launched top-down initiatives such as the extractive reserves in marine coastal areas, often without local support. In these coastal fisheries, the fishers sometimes find themselves involved in processes for the creation of extractive reserves without knowing what kind of institution this novelty represents or understanding the implications of institutional changes and management rules. Itaipu Beach illustrates such a case (Begossi 2004a). As 
Fig. 9. Local newspaper, O Jornal da Região, Niterói, Rio de Janeiro State.
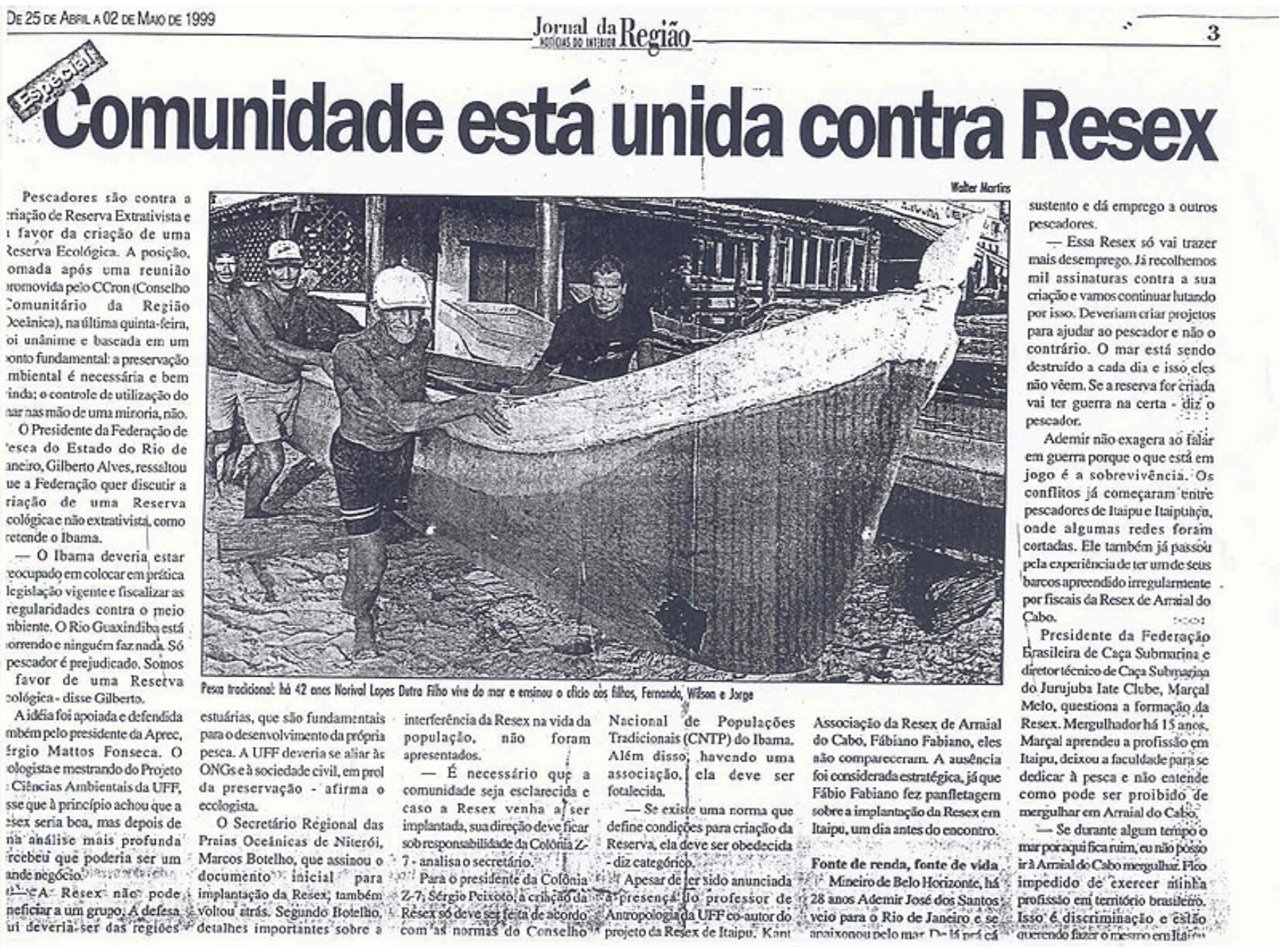

seen in Fig. 9, the newspaper Jornal da Região featured a story on a local fisher movement against the transformation of the beach into an extractive reserve. Local fishers argued that they had no information on the objectives or the functions of such reserves, among other issues.

\section{Territoriality, institutions, and co-management}

Institutions are sets of rights and obligations, including the system of property rights, laws, contracts, and norms. Transaction costs are the costs of enforcing those rights, obligations, and agreements. They include search and bargaining costs such as the costs of negotiations (van der Burg 2000). Within fisheries, transaction costs are usually high because of the uncertainty of the environment and the supply. Nielsen (2003) divided management transaction costs within fisheries into four types: (1) information costs such as data collection and research; (2) decision-making costs such as rule making, fishing rights, and regulations; (3) operational costs or the costs of undertaking fishing activities; and (4) monitoring, control, and enforcement costs, which are determined by the complexity of applicable regulations and by how legitimate these regulations can be for fishers. As suggested by Hanna (2003), a bottom-up approach increases transaction costs such as the cost of 
information, collective decisions, and collective operations. Considering that most management of artisanal fishing in Brazil has been represented by top-down initiatives from the federal government, the cost of implementation should not be as high, but the cost of monitoring and enforcement should be much higher. Many studies have examined such top-down, centralized management in Brazil, including Begossi (2004a), Begossi and Brown (2003), Kalikoski and Satterfield (2004), Seixas (2004b), and Silva (2004). Seixas (2004b) analyzed four case studies in Brazil: the Ceará Reservoir Project in the northeast, the Maritime Extractive Reserve in Arraial do Cabo in the southeast, the Lagoa dos Patos Forum, and the Lagoa de Ibiraquera Project in the south. She found common features in all four cases, such as the lack of government support or recognition of co-management institutions, the users' lack of trust in governmental agencies, and barriers for participatory research and management such as the marginalization of artisanal fishers, the culture of patron-client relations, and corruption, among others. In a study of the maritime extractive reserve of Arraial do Cabo, Silva (2004) analyzed maritime extractive reserves that were created by the central government. She noted ineffective monitoring systems and negative interactions between fishers and the government, especially when represented by the IBAMA, an organization that fishers feel is riddled with corruption and inefficiency. These are examples in which transaction costs have been very high following the implementation of co-management systems, because in the maritime extractive reserves there is little trust in government initiatives, minimal participatory involvement in the co-management design and projects, and little empowerment. Nielsen et al. (2004) observed that one of the main reasons for the lack of success of the modern fisheries management approach was that the topdown approach left fishing communities completely out of the process.

Part of the transaction costs on the southeastern Brazilian coast derives from a lack of local organizations compared to other areas such as Amazonian rivers (Begossi 1998b). The artisanal fishers of the Amazon and the Atlantic Forest coast have much in common, including their technologies, the use of paddled canoes, their highbiodiversity environments, and their interactions with the forest (Begossi 2004b). On the other hand, in the Amazon, there are examples of relatively successful co-management regimes such as the
Mamirauá State Reserve and the federal Upper Juruá Extractive Reserve created from a historical local movement (Begossi 1998b, 2002, Begossi et al. 1999, Begossi and Brown 2003). However, the government's proposal to create a maritime extractive reserve at Itaipu Beach, which was rejected by local fishers and by the local association, illustrates a coastal case in which there is a viable local organization, including the first president elected by the Colônia de Pescadores (Barbosa et al. 2004). In addition, local fishers felt the necessity to be aware, and part, of an institutional change that would directly affect their lives and shift the power of decision making from the local, i.e., association and municipality, to the federal level, i.e., the IBAMA.

Management is a local exercise that should use local rules and institutions. Berkes (2002) suggested that the replacement of local institutions by centralized ones should involve a change in the way knowledge is used for management. He observed that the shift in knowledge systems is one of the major impacts of government-level institutions, because it is accompanied by a change in control over resources. Fishers from Itaipu Beach at least seemed aware that changes could not be in the direction they wanted. Of course, there are many possible management arrangements. For general examples of designs and arrangements of co-management regimes, see Ostrom et al. (2002), and, for examples within fisheries, see Sen and Nielsen (1996) and Wilson et al. (2003). McCay (2002) used the concept of "embeddedness" to emphasize the need for finegrained, long-term historical and ethnographic research on common-pool resource situations and their contexts. The existence of institutions, according to this author, can lower transaction costs. Jentoft (2005) suggested that empowerment is enabling and authorizing, and that fishers would be empowered when institutions facilitate their participation and secure their rights. Empowerment of artisanal coastal fishers in Brazil would involve current local rules, local knowledge, and local organizations, along with the ability to see the resulting co-management institution as the product of participatory co-management projects and not as an a priori institution, already established and designed. As highlighted by Pomeroy et al. (2001) in a review of co-management projects in Asia, empowerment allows communities to be free from many of the bureaucratic requirements of government's central administrative agencies. This type of flexibility generally facilitates the control 
and management by communities of the resource and resource users.

Forms of diminishing transaction costs include the use of current local knowledge and customary rules to build up co-management processes. Ruddle (2000) described the local knowledge of coastal fishers and emphasized its importance for modern management. Other authors (Berkes 1985, 1999, Berkes et al. 2001) have analyzed local knowledge and its applications for the management of fisheries as well as for other systems. The informal division in the use of fishing spots, indicating a division of resources that avoids overlap in the exploitation of marine areas in Brazil, was demonstrated in earlier studies (Begossi 2001a,b, Begossi and Brown 2003), and the temporal stability of such a division is shown in this study. Existing rules of this type could form a basis for co-management.

According to Jentoft (2003), existing institutional structures can be used for co-management, new management institutions must be related to existing institutions, and co-management should not be created in an institutional vacuum. The management of resources may also be seen as an "institutional problem" (Acheson 2000), and, considering the reality in Third World or developing countries, corruption is regarded as one of the causes of government failure, along with the disinterest of the state and the high transaction costs of monitoring enforcement. Institutional approaches to comanagement are known from the literature, and they include analysis of collective actions (Ostrom 1990, Ostrom et. al. 2002). Examples of collective actions and successes in co-management are provided by some of the Amazonian fisheries in Brazil, such as the Mamirauá Sustainable Reserve and São Miguel Island on the Lower Amazon River, which were successful in managing pirarucu (Arapaima gigas) by monitoring and using local knowledge and local fishers (Queiroz and Crampton 1999, Padoch et al. 1999, Begossi 2002, Castro 2004). The Pacific coast has also experienced some success with comanagement projects, e.g., the analysis given by Hickey and Johannes (2002) of local management in Vanuatu. Others, such as Ruttan (1998), observed that resources might be best managed collectively, rather than privately, illustrating such an approach by studying the management of Trochus in Maluku, Indonesia.

Among other aspects, the obstacles to be overcome in managing such small-scale local fisheries are based on the weak capability to exclude outsiders such as industrial fishers or tourists. The behavior observed by industrial fishers who use large to medium-sized boats and, according to the local inhabitants, spend part of their lives working embarcado, i.e., outside the village in a fishing boat, could serve as an illustrative comparative example. One of the informants, a fisher from Picinguaba, works sporadically embarcado, staying about a week at sea in a 5-12 t boat and fishing with lines and nets. On 22 October 2003, the locations of the fishing spots he was able to mark with a GPS from the boat (Fig. 10) were made available. The 365 spots marked and fished from his boat showed that a long distance is covered, from the middle of São Paulo State up to the city of Rio de Janeiro. In Picinguaba, Masumoto (2003) also showed that industrial fishers, in this case represented by three owners of four boats at Picinguaba, used spots from the coast of São Paulo to the coast of Rio de Janeiro State. What is still uncertain is the extent to which industrial fishers are entering the area of artisanal fishers, because some argue that the former fish in deeper waters than the latter.

The invasion of riverine or shore waters by industrial fishers was observed in the Amazon by Petrere (1989), McGrath et el. (1993), and Castro et al. (2002), and on the southeastern coast by Begossi (1995, 2001a, 2004a), Seixas and Begossi (1998), and Kalikoski et al. (2002). Considering that an informal division of fishing spots is already in effect among coastal Brazilian fishers (Begossi $2001 a, b)$, the temporal stability of fishing spots is a factor that could provide strong support to local management of the fisheries through the reservation of areas for artisanal fishing. The robustness of this stability is evident in the fact that the location of the spots did not move, in spite of technological changes at Valença, Bahia, e.g., a switch from fishing with the rede de calão to the increased use of the redinha for catching shrimp. Moreover, despite the advanced urbanization of Itaipu Beach, Niterói, the spots used are still the same. Of course, the effects of future changes in fishing technology or even increased industrialization and tourism on the use of the fishing space are hard to predict. Nevertheless, it can be concluded that the maintenance of such stability seems, in a certain form, strictly associated with the day-to-day reinforcement of the fishing spots through the use of the spots by the fishers, as shown in the example of the Almada-Picinguaba interaction in Fig. 7. 
Fig. 10. Fishing spots used by 5-12 t boats, marked by a fisher from Picinguaba. Data were obtained by a fisher who uses lines and nets in a boat that stays out of Picinguaba for about a week. Data included 365 fishing spots.

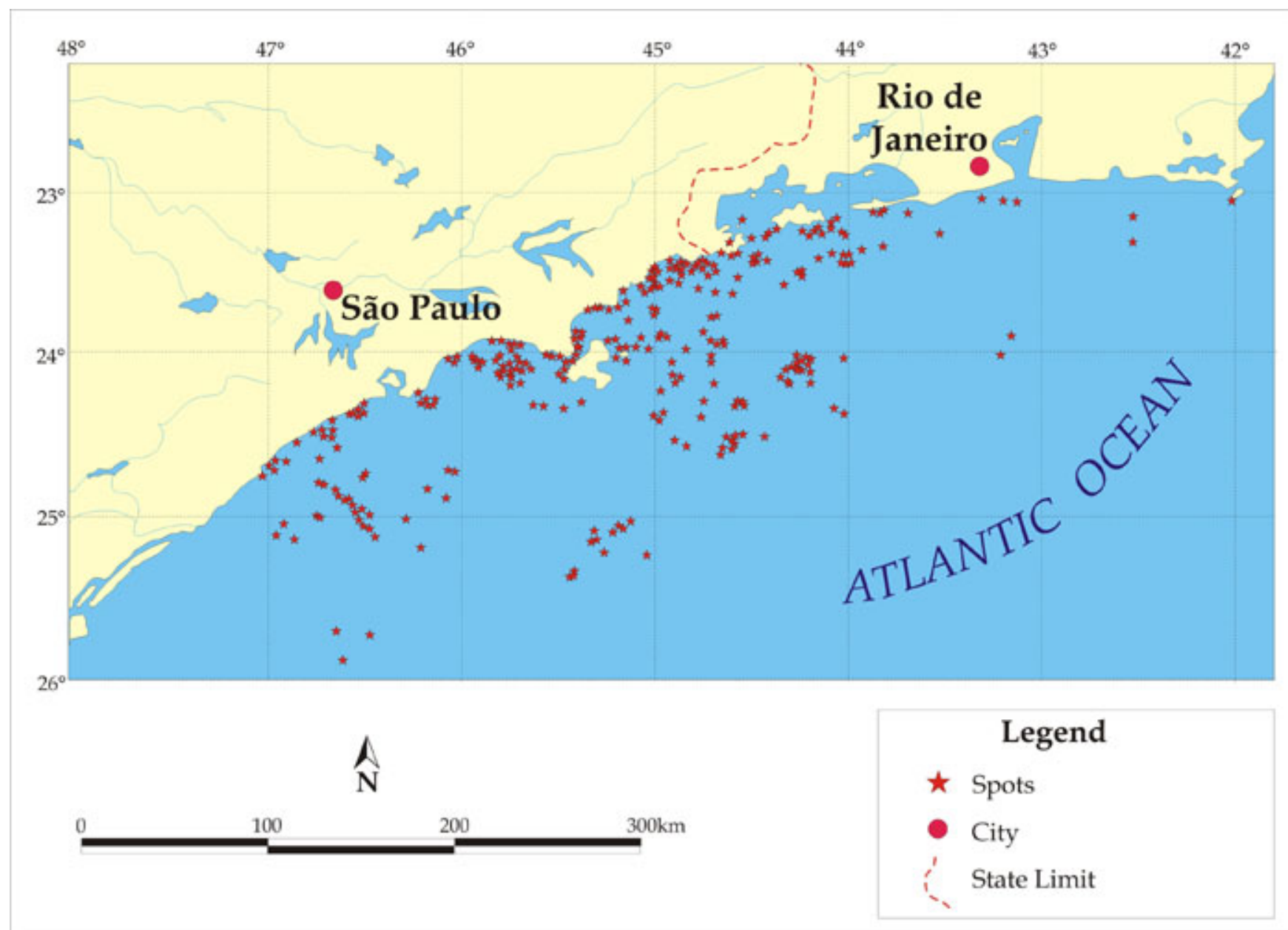

\section{Complexity and institutional arrangements}

Fisheries in Japan have had marine area reserves in their civil code for artisanal inshore fisheries since 1902 (Akimichi and Ruddle 1984), because, at that time, the village sea territories that were established during the feudal era had already been mapped. In the case of the Brazilian coast, where there is an informal division of sea space among local artisanal fishers and where we found a long temporal stability in the use of these spots, a management solution for these fisheries might be to reserve or to designate these areas for artisanal fishing. Designated areas of this type could be used to support the local fishers' claims against outsiders (Begossi 1995). Such a solution, i.e., areas designated for local fisheries based on the fishing spots used, if supported by the Colônias de Pescadores or associations of fishers, might also grow into co-management institutions, starting with fisher participation based on existing rules. Acheson and Wilson (1996) observed that, at seven fisheries in which management is influenced by science and managed by the central government and in 29 societies in which there is a strong basis for folk-management techniques, resources are managed by political institutions that have riparian rights over coastal areas, i.e., a rule or regulation 
can apply only within the territory of a group willing and able to enforce it.

In terms of political and institutional changes, less complex institutional arrangements, such as the demarcation of fishing space for artisanal fishers, might represent a realistic way to incorporate local rules. Such a solution could include the demarcation of the fishing space for each community, considering that an incipient division of the space already exists and that it is relatively stable in time. This type of institution does not shift the local power to a central power such as federal environmental agencies, as occurs in the maritime extractive reserves. Less complex institutional arrangements already exist in the Amazon with regard to the comanagement of Amazonian lakes in the form of "fishing accords" (McGrath et al. 1993, Castro 2000, Castro and McGrath 2001, Begossi and Brown 2003), and include rules based on customary laws. In the Amazon, conflicts between local fishers and commercial fisheries gave rise to formal mechanisms for controlling fishery resources, with the historical support of the Amazonian Catholic Church (Castro et al. 2002). These authors analyzed the fishing accord for the Island of São Miguel on the Amazon River. The accord, established $25 \mathrm{yr}$ ago, included four stages: (1) the old fishing strategy was affected by the intensification of regional fisheries; (2) an incipient fishing management scheme was established; (3) the fishery rules were improved to solve emerging problems; and (4) the community is currently extending a net to external communities, assuming the commercialization of fish as part of the management system. Other examples are provided by the lake management system on the Solimôes River in the Tefé region, in which 330 lakes are managed by 26 communities, each of which has different categories for the lakes, e.g., fish procreation, sanctuaries, conservation, subsistence fishing, and free access (Oliveira and Cunha 2002).

Complexity represents an important obstacle to resource management (Poteete and Wilch 2004). Considering that management can be an exercise in collective institutional development, the cited authors analyzed how important the complexity of a resource is for collective action to manage forest resources. In the case of fisheries, the use of existing institutions could reduce the complexity of change in the institutional arrangements, the transaction costs, and the difficulties in monitoring the management process. The fishing accords mentioned in the context of the lake system on the Amazon floodplain might serve as an example of a way to reduce complexity and increase the power of co-management systems.

\section{CONCLUSIONS}

The results shown here suggest that local management in the form of co-management does not necessarily apply in complex institutional reorganizations as long as there are customary rules in place. In the case of the coastal fishers in Brazil, there is a spatial arrangement under an informal division of spots (Begossi 2001a,b, Begossi and Brown 2003) that has proven to be stable over time, as observed in the present study. Therefore, the local rules for co-management are straightforward, and in this case co-management might represent the state's recognition of the rights of local artisanal fishers over the use of these fishing areas.

However, there is no guarantee whatsoever that the informal division of spots, their local use, and their stability over time is supporting sustainable fisheries. For example, at Puruba Beach, a decrease in the number and diversity of fish landings was observed by Lopes (2004). Nevertheless, one of the main obstacles to the analysis of the sustainability of Brazilian fisheries is the lack of data on fish landings. One might speculate to what extent the relatively low density of artisanal fishers on the southeast Brazilian coast, especially those who fish in paddled or motorized canoes, contributes to the sustainability of these artisanal fisheries. On the other hand, despite the nonoverlapping use of fishing spots observed among resident fishers, tourism and industrial fishing may disrupt the process if there is no control or monitoring of these activities. In spite of the assertion that industrial fishers are located in deeper waters, there is a real possibility that they could and do invade artisanal fishing waters. Figure 10 shows such an example, and it is not uncommon to observe trawlers and large boats very close to shore.

The temporal stability observed in the use of fishing spots among fishers from the southeastern Atlantic Forest coast could be, on its own, a solid justification for using local institutions to support local management: stability of this type shows that, over a period of 10-30 yr, there has been no sequential exploitation of spots, i.e., by adding other spots from neighboring beaches or by looking for more distant 
spots. For example, the Rasa and Redonda Islands in Rio de Janeiro are distant spots, still used sporadically by Copacabana and Itaipu fishers. The case of Almada-Picinguaba beaches, shown in Fig. 7, appears to be a result of a vacant space left by Picinguaba fishers. By not adding other spots, this type of behavior maintains a division in the use of the marine space and a local characteristic in the exploitation of resources from each of the fisheries studied; such features contribute to the sustainability of the local fisheries. Briefly, the perspectives obtained through the results of this study are that:

- the stability of spots and their local exploitation by resident fishers deserve attention and could be used to manage the fishery for the benefit of local users;

- the management and control of other users such as tourists, boats, and trawlers should be settled in a way that allows the local artisanal fisheries to continue;

- it would be worthwhile to know if temporal changes occur in the productivity of the main spots used for fishing. Monitoring some spots reserved for local coastal artisanal fishers and other spots shared with other users, e.g., tourists, would be an interesting way to track the sustainability of these fisheries; and

- $\quad$ studies of the ways in which medium-sized boats, i.e., 5-12 t, and industrial fishers use marine space should be carried out to determine if they are also fishing in the spots normally used by local artisanal fishers.

Responses to this article can be read online at:

http://www.ecologyandsociety.org/voll1/iss1/art5/responses/

\section{Acknowledgments:}

A preliminary version of this paper was presented at the XIIMeeting of the Society for Human Ecology, Cozumel, Mexico, 20 February 2004, and I thank FAPESP and CNPq for grants and scholarships, including expenses to attend this meeting. FAPESP fieldwork grants were \# 97/06167-0, 01/718-1, and 01/05263, and CNPq grants were 302340/88-2 and
300708/2004-1. I am grateful to Eduardo Camargo for his valuable help in the fieldwork and to Celia Futemma and Cristiana S. Seixas for valuable comments and suggestions. Maps were made by Salvador Carpi, Jr., and the English revision was done by Diane Petty. Finally, I am grateful for insightful comments by the referees and editors.

\section{LITERATURE CITED}

Acheson, J. M. 1972. Territories of lobstermen. Natural History 81:60-79.

Acheson, J. M. 1981. The lobster fiefs: economic and ecological effects of territoriality in the Maine lobster industry. Human Ecology 3:183-207.

Acheson, J. M. 1987. The lobster fiefs revisited: economic and ecological effects of territoriality in the Maine lobster industry. Pages 37-65 in B. McKay and J. M. Acheson, editors. The question of the commons: the culture and ecology of communal resources. University of Arizona Press, Tucson, Arizona, USA.

Acheson, J. M. 1997. The politics of managing the Maine lobster industry: 1860 to the present. Human Ecology 25(1):3-27.

Acheson, J. M. 2000b. Varieties of institutional failure. Available online at:

http://dlc.dlib.indiana.edu/archive/00000195/.

Acheson, J. M., and J. Knight. 2000. Distribution fights, coordination games, and lobster management. Comparative Studies in Society and History 42(1): 209-238.

Acheson, J. M., and J. A. Wilson. 1996. Order out of chaos. American Anthropologist 98(3):579-594.

Acheson, J. M., J. A. Wilson, and R. S. Steneck. 1998. Managing chaotic fisheries. Pages 390-414 in F. Berkes, C. Folke, and J. Colding, editors. Linking social and ecological systems. Cambridge University Press, Cambridge, UK.

Agrawal, A. 2002. Common resources and institutional sustainability. Pages $41-85$ in $\mathrm{E}$. 
Ostrom, T. Diez, N. Dolsak, P. C. Stern, S. Stonich, and E. U. Weber, editors. The drama of the commons. National Academy Press, Washington, D.C., USA.

Akimichi, T., and K. Ruddle. 1984. The historical development of territorial rights and fishery regulations in Okinawan inshore waters. Pages 37-88 in $\mathrm{K}$. Ruddle and T. Akimichi, editors. Maritime institutions in the western Pacific: Senri ethnological studies. National Museum of Ethnology, Osaka, Japan.

Bailey, K. D. 1978. Methods of social research. The Free Press, New York, New York, USA.

Barbosa, S. R., S. da Cal, and A. Begossi. 2004. Fisheries, gender, and local changes at Itaipu Beach, Rio de Janeiro, Brazil: an individual approach. MultiCiencia 2:1-14. [online] URL:

www.multiciencia.unicamp.br/artigos 02/rede 3.pdf.

Begossi, A. 1995. Fishing spots and sea tenure in Atlantic Forest coastal communities: incipient forms of local management. Human Ecology 23 (3):387-406.

Begossi, A. 1998a. Property rights for fisheries at different scales: applications for conservation in Brazil. Fisheries Research 34:269-278.

Begossi, A. 1998b. Cultural and ecological resilience among caiãaras of the Atlantic Forest and caboclos of the Amazon, Brazil. Pages 129-157 in C. Folke and F. Berkes, editors. Linking social and ecological systems. Cambridge University Press, Cambridge, UK.

Begossi,A. 2001 $a$. Mapping spots: fishing areas and territories on the Atlantic Forest coast, Brazil. Regional Environmental Change 2:1-12.

Begossi, A. 2001b. Cooperative and territorial resources: Brazilian artisanal fisheries. Pages 109-130 in J. Burger, R. Norgaard, E. Ostrom, D. Policansky, and B. Goldstein, editors. Protecting the commons: a framework for resource management in the Americas. Island Press, Washington, D.C., USA.

Begossi, A. 2002. The sustainable development reserve of Mamiraua, Amazonas State, Brazil. Pages 64-84 in D. C. Wilson, A. Hough, A. Jarre, S. Sverdrup-Jensen, M. Ahmed, A. Begossi, S.
Donda, and M. Pido, editors. Guidelines for the assessment of small-scale fisheries against the MSC standard: a report to the Marine Stewardship Council. Institute for Fisheries Management and Coastal Community Development, Hirtshals, Denmark.

Begossi, A. 2004a. Áreas, pontos de pesca, pesqueiros e territórios na pesca artesanal. Pages 223-253 in A. Begossi, editor. Ecologia de pescadores da Mata Atlântica e da Amazônia. Editora Hucitec, São Paulo, Brazil.

Begossi, A. 2004b. Introdução: ecologia humana. Pages 13-36 in A. Begossi, editor. Ecologia de pescadores da Mata Atlântica e da Amazônia. Editora Hucitec, São Paulo, Brazil.

Begossi, A., and D. Brown. 2003. Experiences with fisheries co-management in Latin America and the Caribbean. Pages 135-150 in D. C. Wilson, J. R. Nielsen, and P. Degnbol, editors. The fisheries comanagement experience: accomplishments, challenges, and prospects. Fish and Fisheries Series, Number 26. Kluwer Academic, Dordrecht, The Netherlands.

Begossi, A., Hanazaki, N., and Peroni. 2000. Knowledge and use of biodiversity in Brazilian hot spots. Environment, Development, and Sustainability 2(3/4):177-193.

Begossi, A., R. A. M. Silvano, B. D. Amaral, and O. Oyakawa. 1999. Uses of fish and game by inhabitants of an extractive reserve (Upper Juruá, Acre, Brazil). Environment, development, and sustainability 1:1-21.

Berkes, F. 1985. Fishermen and the tragedy of the commons. Environmental Conservation 12:199-206.

Berkes, F., editor. 1989. Common property resources: ecology and community-based sustainable development. Belhaven Press, London, UK.

Berkes, F. 1999. Sacred ecology: traditional ecological knowledge and resource management. Taylor and Francis, Philadelphia, Pennsylvania, USA.

Berkes, F. 2002. Cross-scale cultural linkages: perspectives from the bottom up. Pages 293-321 in E. Ostrom, T. Diez, N. Dolsak, P. C. Stern, S. Stonich, and E. U. Weber, editors. The drama of the commons. National Academy Press, Washington, 
D.C., USA.

Berkes, F., R. Mahon, P. McConney, R. Pollnac, and R. Pomeroy. 2000. Managing small-scale fisheries: alternative directions and methods. International Research Development Centre, Ottawa, Ontario, Canada.

Burke, B. E. 2001. Hardin revisited: a critical look at perception and the logic of the Commons. Human Ecology 29:449-476.

Burger, J., C. Field, R. B. Norgaard, E. Ostrom, and D. Policansky. 2001. Common-pool resources and commons institutions. Pages 1-15 in J. Burger, E. Ostrom, R. B. Norgaard, D. Policansky, and B. D. Goldstein, editors. Protecting the commons: a framework for resource management in the Americas. Island Press, Washington, D.C., USA.

Castro, F. 2000. Fishing accords: the political ecology of fishing intensification in the Amazon. Dissertation, Indiana University, Bloomington, Indiana, USA.

Castro, F. 2004. N\&\#0237veis de decisão e o manejo dos recursos pesqueiros. Pages 255-284 in A. Begossi, editor. Ecologia de pescadores da Mata Atlântica e da Amazônia. Editora Hucitec, São Paulo, Brazil.

Castro, F., and D. McGrath. 2001. O manejo comunitário dos lagos na Amazônia. Pages 112-126 in Parcerias estratégicas, Centro de Estudos Estratégicos, Ministério da Ciência e Tecnologia, Brasília, Brazil.

Castro, F., D. McGrath, and M. Crossa. 2002. Adaptandose a los cambios: la habilidad de las comunidades riberenas en el manejo de sistemas de lagos de la Amazonia brasilena. Pages 272-303 in R. C. Smith and D. Pinnedo, editors. El cuidado de los bienes comunes, gobierno y manejo de los lagos $y$ bosques en la Amazonia.Instituto del Bien Comum, Instituto de Estudios Peruanos, Lima, Peru.

Cordell, J. 1974. The lunar-tide fishing cycle in Northeast Brazil. Ethnology 13:379-392.

Cordell, J. 1978. Carrying capacity analysis of fixed territorial fishing. Ethnology 17:1-24.

Cordell, J. 1985. Sea tenure in Bahia. National
Academy of Sciences, National Research Council, Washington, D.C., USA.

Cordell, J., editor. 1989. A sea of small boats. Cultural Survival Inc., Cambridge, Massachusetts, USA.

Davidson-Hunt, I., and F. Berkes. 2003. Learning as you journey: Anishinaabe perception of socialecological environments and adaptive learning. Ecology and Society 8(1):5. [online] URL: http://www.ecologyandsociety.org/vol8/iss1/art5/.

Diegues, A. C. S. 1983. Pescadores, camponeses, e trabalhadores do mar. Ática, São Paulo, Brazil.

Dietz, T., N. Dolsak, E. Ostrom, and P. Stern. 2002. The drama of the commons. Pages 3-35 in E. Ostrom, T. Diez, N. Dolsak, P. C. Stern, S. Stonich, and E. U. Weber, editors. The drama of the commons. National Academy Press, Washington, D.C., USA.

Feeny, D., F. Berkes, B. McCay, and J. M. Acheson. 1990. The tragedy of the commons: twenty-two years later. Human Ecology 18:1-19.

Forman, S. 1967. Cognition and the catch: the location of fishing spots in a Brazilian coastal village. Ethnology 6:417-426.

Hanazaki, N. 1997. Conhecimento e uso de plantas, pesca e dieta em comunidades caiçaras do Município de Ubatuba SP. Thesis, University of São Paulo, São Paulo, Brazil.

Hanazaki, N, H. F. Leitão-Filho, and A. Begossi. 1996. Uso de recursos na Mata Atlântica: o caso da Ponta do Almada. Interciência, Revista de Ciencia y Tecnologia, Caracas, Venezuela. 21(5):1-8.

Hanazaki, N., J. Y. Tamashiro, H. F. Leitão-Filho, and A. Begossi. 2000. Diversity of plant uses in two caiçara communities from the Atlantic Forest Coast, Brazil. Biodiversity and Conservation 9:597-615.

Hanazaki, N., and A. Begossi. 2000. Fishing and niche dimension for food consumption of caiçaras from Ponta do Almada (Brazil). Human Ecology Review 7(2):52-62.

Hanna, S. 2003. The economics of co-management. Pages 51-60 in D. C. Wilson, J. R. Nielsen, and P. Degnbol, editors. Fisheries co-management 
experiences in Latin America and the Caribbean. Fish and Fisheries Series, Number 26. Kluwer Academic, Dordrecht, The Netherlands.

Hickey, F. R., and R. E. Johannes. 2002. Recent evolution of village-based marine resource management in Vanuatu. Traditional Marine Resource Management and Knowledge Information Bulletin 14. [online] URL:

www.spc.org.nc/coastfish/News/Trad/trad.htm.

Jentoft, S. 2003. Co-management-the way forward. Pages 1-14 in D. C. Wilson, J. R. Nielsen, and P. Degnbol, editors. Fisheries co-management experiences in Latin America and the Caribbean. Fish and Fisheries Series, Number 26. Kluwer Academic, Dordrecht, The Netherlands.

Jentoft, S. 2005. Fisheries co-management as empowerment. Marine Policy 29:1-7.

Kalikoski, D., Vasconcellos, M., and L. Lavkulich. 2002. Fitting institutions to ecosystems: the case of artisanal fisheries management in the estuary of Patos Lagoon. Marine Policy 26:179-196.

Kalikoski, D. C., and T. Satterfield. 2004. On crafting a fisheries co-management arrangement in the estuary of Patos Lagoon (Brazil): opportunities and challenges faced through implementation. Marine Policy 28:503-522.

Kopelman, S., J. M. Weber, and D. M. Messick. 2002. Factors influencing cooperation in commons dilemmas: a review of experimental psychological research. Pages 113-156 in E. Ostrom, T. Diez, N. Dolsak, P. C. Stern, S. Stonich, and E. U. Weber, editors. The drama of the commons. National Academy Press, Washington, D.C., USA.

Lima, K. R., and L. F. Pereira. 1997. Pescadores de Itaipu; meio ambiente, conflito e ritual no litoral do estado do Rio de Janeiro. Editora da Universidade Federal Fluminense (EDUFF), Niterói, Rio de Janeiro, Brazil.

Lopes, P. F. M. 2004. Ecologia caiçara: pesca, dieta e alocação de tempo na comunidade da Praia do Puruba. Thesis, Universidade Estadual de Campinas, Unicamp, São Paulo, Brazil.

Masumoto, C. 2003. As atividades pesqueiras da comunidade caiçara de Picinguaba (Ubatuba, São
Paulo). Thesis, Instituto Oceanográfico de São Paulo, São Paulo, Brazil.

McCay, B. 2002. Emergence of institutions for the commons: contexts, situations, and events. Pages 361-402 in E. Ostrom, T. Diez, N. Dolsak, P. C. Stern, S. Stonich, and E. U. Weber, editors. The drama of the commons. National Academy Press, Washington, D.C., USA.

McCay, B., and J. M. Acheson. 1987. Questions of the commons. University of Arizona Press, Tucson, Arizona, USA.

McGrath, D., F. Castro, C. Futemma, B. Amaral, and J. Calábria. 1993. Fisheries and the evolution of resource management on the lower Amazon floodplain. Human Ecology 21:167-195.

Nehrer, R. 1997. Colônia de Pescadores do Posto 6: tecnologia e estratégias de uso de recursos. Thesis, Universidade Federal do Rio de Janeiro, Rio de Janeiro, Brazil.

Nehrer, R., and A. Begossi. 2000. Fishing at Copacabana, Rio de Janeiro: local strategies in a global city. Ciência e Cultura 52(1):26-30.

Nielsen, J. R. 2003. An analytical framework for studying: compliance and legitimacy in fisheries management. Marine Policy 27:425-432.

Nielsen, J. R., P. Degnbol, K. Kuperan Viswanathan, M. Ahmed, M. Hara, and N. M. R. Abdullah. 2004. Fisheries co-management-an institutional innovation? Lessons from South East Asia and Southern Africa. Marine Policy 28:151-160.

Oliveira, A. C., and L. H. Cunha. 2002. Manejo comunitário de lagos em la planície inundable de la cuenca media Del Rio Solimões, Brasil. Pages 244-271 in R. C. Smith and D. Pinnedo, editors. El cuidado de los bienes comunes, gobierno y manejo de los lagos y bosques en la Amazonia. Instituto del Bien Comum, Instituto de Estudios Peruanos, Lima, Peru.

Ostrom, E. 1990. Governing the commons: the evolution of collective institutions for collective action. Cambridge University Press, Cambridge, UK.

Ostrom, E., T. Diez, N. Dolsak, P.C. Stern, S. 
Stonich, and E. U. Weber, editors. 2002. The drama of the commons. National Academy Press, Washington, D.C., USA.

Padoch, C., M. Ayres, M. Pinedo-Vasquez, and A. Henderson. 1999. Várzea-diversity, development, and conservation of Amazonian's white-water floodplains. New York Botanical Garden, New York, New York, USA.

Petrere, M., Jr. 1989. River fisheries in Brazil: a review. Regulated Rivers: Research and Management. 4:1-16.

Pomeroy, R. S., B. M. Katon, and I. Harkes. 2001. Conditions affecting the success of fisheries comanagement: lessons from Asia. Marine Policy 25:197-208.

Poteete, A. R., and D. Welch. 2004. Institutional development in the face of complexity: developing rules for managing forest resources. Human Ecology 32(3):279-311.

Queiroz, H. L., and W. G. R. Crampton. 1999. Estratégias para manejo de recursos pesqueiros em Mamiraua. Sociedade Civil Mamiraua, MCTCNPq, Brazilia, Brazil.

Ruddle, K. 2000. Systems of knowledge: dialogue, relationships, and process. Environment, Development and Sustainability 2(3/4):277-304.

Ruttan, L. M. 1998. Closing the commons: cooperation for gain or restraint? Human Ecology 26(1):43-66.

Seixas, C. S. 2004a. Instituiçôes e manejo pesqueiro: o caso da Lagoa de Ibiraquera, S. C. Pages 285-312 in A. Begossi, editor. Ecologia de pescadores da Mata Atlântica e da Amazônia. Editora Hucitec, São Paulo, Brazil.

Seixas, C. S. 2004b. Barriers to local-level participatory ecosystem assessment and management in Brazil. [online] URL:

http://www.millenniumassessment.org/documents/ bridging/papers/seixas.cristiana.pdf.

Seixas, C.S., and A. Begossi. 1998. Do fishers have territories? The use of fishing grounds at Aventureiro (Ilha Grande, Brazil). Digital Library of the Commons, Indiana University, Bloomington, Indiana, USA. [online] URL:

http://dlc.dlib.indiana.edu/archive/00000155/.
Seixas, C. S., and F. Berkes. 2003. Dynamics of social-ecological changes in a lagoon fishery in southern Brazil. Pages 271-298 in F. Berkes, J. Colding, and C. Folke, editors. Navigating socioecological systems. Cambridge University Press, Cambridge, UK.

Sen, S., and J. R. Nielsen. 1996. Fisheries comanagement: a comparative analysis. Marine Policy 20:405-418.

Silva, P. P. 2004. From common property to comanagement: lessons from Brazil's first maritime extractive reserve. Marine Policy 28:419-428.

Silvano, R. A. M. 2004. Pesca artesanal e etnoictiologia. Pages 187-222 in Ecologia de Pescadores da Mata Atlântica e da Amazônia. A. Begossi, editor. Editora Hucitec, São Paulo, Brazil.

van der Burg, T. 2000. Neo-classical economics: institutional economics and improved fisheries management. Marine Policy 24:45-51.

Wilson, D. C., R. Nielsen, and P. Degnbol. 2003. Fisheries co-management experiences in Latin America and the Caribbean. Fish and Fisheries Series, Number 26. Kluwer Academic, Dordrecht, The Netherlands.

Wilson, J. 2002. Scientific uncertainty, complex systems, and the design of common-pool institutions. Pages 327-359 in E. Ostrom, T. Diez, N. Dolsak, P. C. Stern, S. Stonich, and E. U. Weber, editors. The drama of the commons. National Academy Press, Washington, D.C., USA. 